\title{
Correlation of physical and chemical attributes of soil with sugarcane yield
}

\author{
Domingos Guilherme Pellegrino Cerri(1) and Paulo Sérgio Graziano Magalhães(1)
}

(1)Universidade Estadual de Campinas, Departamento de Engenharia Agrícola, Avenida Candido Rondon, no 501, CEP 13081-875 Campinas, SP, Brazil. E-mail: dgpcerri@terra.com.br, graziano@agr.unicamp.br

\begin{abstract}
The objective of this work was to evaluate the correlation between sugarcane yield and some physical and chemical attributes of soil. For this, a 42-ha test area in Araras, SP, Brazil, was used. Soil properties were determined from samples collected at the beginning of the 2003/2004 harvest season, using a regular 100x100 m grid. Yield assessment was done with a yield monitor (Simprocana). Correlation analyses were performed between sugarcane yield and the following soil properties: $\mathrm{pH}, \mathrm{pH} \mathrm{CaCl}, \mathrm{N}, \mathrm{C}$, cone index, clay content, soil organic matter, $\mathrm{P}, \mathrm{K}, \mathrm{Ca}, \mathrm{Mg}, \mathrm{H}+\mathrm{AL}$, cation exchange capacity, and base saturation. Correlation coefficients were respectively $-0.05,-0.29,0.33,0.41,-0.27,0.22,0.44,-0.24$, trace, $-0.06,0.01,0.32,0.14$, and 0.04. Correlations of chemical and physical attributes of soil with sugarcane yield are weak, and, per se, they are not able to explain sugarcane yield variation, which suggests that other variables, besides soil attributes, should be analysed.
\end{abstract}

Index terms: Saccharum officinarum, precision agriculture, soil sampling, spatial variation, variation structure.

\section{Correlação de atributos físicos e químicos do solo com a produtividade de cana-de-açúcar}

\begin{abstract}
Resumo - O objetivo deste trabalho foi avaliar as correlações entre a produtividade da cana-de-açúcar e alguns atributos físicos e químicos do solo. Para isso, uma área de 42 ha, em Araras, SP, foi selecionada. As propriedades do solo foram determinadas a partir de amostras coletadas no início da safra 2003/2004, por meio de uma grade regular de 100x100 m. A produtividade foi avaliada por meio de um monitor de produtividade (Simprocana). Análises de correlação foram realizadas entre a produtividade da cana-de-açúcar e as seguintes propriedades do solo: $\mathrm{pH}, \mathrm{pH} \mathrm{CaCl} \mathrm{Cl}_{2}, \mathrm{~N}, \mathrm{C}$, índice de cone, teor de argila, matéria orgânica, $\mathrm{P}, \mathrm{K}, \mathrm{Ca}, \mathrm{Mg}, \mathrm{H}+\mathrm{Al}$, capacidade de troca catiônica e saturação por bases. Os coeficientes de correlação foram respectivamente de $-0,05,-0,29$, $0,33,0,41,-0,27,0,22,0,44,-0,24$, traço, $-0,06,0,01,0,32,0,14$ e 0,04 . As correlações de atributos químicos e físicos do solo com a produtividade da cana-de-açúcar são baixas, por si mesmas, e não são capazes de explicar a variação na produtividade da cana-de-açúcar, o que indica que, além das propriedades do solo, outras variáveis devem ser analisadas.
\end{abstract}

Termos para indexação: Saccharum officinarum, agricultura de precisão, amostragem de solo, variação espacial, estrutura de variação.

\section{Introduction}

By combining yield maps, topographic information and maps of physical and chemical attributes of the soil, it is possible to implement variable fertilizer applications on fields using variable rate technology (Welsh et al., 2003). Because of the high variability of nutrient levels in most agricultural fields, uniform fertilizer applications are likely to lead to excessive fertilization in some areas and to inadequate in others. Goering (1993) maintained that, taking into account the natural variability of production factors, the amount of fertilizer applied can be varied according to a prescribed map. Borgelt et al. (1994) examined the potential for applying fertilizer variable rates (VRT) on fields in order to improve economic performance and minimise environmental impact.

Yield maps can provide a useful basis for applying fertilizer variable rates because they integrate soil, landscape and crop factors together into an expression of relative productivity (Mallarino \& Wittry, 2004). Frogbrook et al. (2002) observed that the stability in the variation structure of nutrients and $\mathrm{pH}$ in soils is important for precision agriculture because, once it has 
been identified for one year, the information can be used for the following two to three years at least.

Sugarcane is a high-yielding crop which requires a significant amount of nutrients, since mineral elements comprise about 3 to $5 \%$ of its dry matter, according to Cantarella \& Rossetto (2010), who have shown that the above-ground portion of sugarcane contains the following nutrients for each $100 \mathrm{Mg}$ of stalks produced: $\mathrm{N}, 100$ to $154 \mathrm{~kg} ; \mathrm{P}_{2} \mathrm{O}_{5}, 15$ to $25 \mathrm{~kg} ; \mathrm{K}_{2} \mathrm{O}, 77$ to $232 \mathrm{~kg}$; and $\mathrm{S}, 14$ to $49 \mathrm{~kg}$.

Researchers have shown that soil test levels for P, $\mathrm{K}$ and lime vary considerably within sugarcane (Corá et al., 2004; Souza et al., 2004; Johnson \& Richard, 2005) and other crop fields (Kravchenko \& Bullock, 2000 ), with coefficients of variation (CV) greater than $30 \%$. Landell et al. (2003) evaluated the effects of the subsurface chemical attributes of Oxisols on the yield of some sugarcane clones, and of the cultivar RB72454 during the first, second and third cropping cycles. The authors verified, from multiple regression analyses, that in the third harvest yield variation for clones could be explained by two attributes: base saturation and phosphorus content. For the cultivar RB72454, 47\% of that variation was explained by the sum of bases and the contents of calcium and organic matter.

Another approach to evaluate and discuss spatial variability related to the soil-plant system, using the state-space stochastic model, was presented by Timm et al. (2003). The authors analysed a 0.21 ha plot, with three treatments and four replicates, and come out with results showing that the spatial series of soil clay content has an effective contribution to describe the number of canes of the crop, and concluded that this alternative analytical tool is adequate to describe the spatial association between different variables along space or time. Therefore, it can be used to understand the complex relationships between yield and soil physical and chemical properties, since it is possible to underline an influence which causes a change in their relation, allowing management optimization of soil resources and sugarcane yield.

Therefore, it is possible to foresee potential benefits in applying VRT in sugarcane fields (Corá \& Beraldo, 2006; Johnson \& Richard, 2010), as has been reported for other crops (Godwin et al., 2003; Hurtado et al., 2009). Analysis of the economic benefits of spatially variable nitrogen application, based on the costs of precision farming hardware, software, and other services for cereal crops showed that the results of nitrogen variable rates of application exceed the returns from uniform application (Godwin et al., 2003).

The objective of this work was to evaluate the correlation between sugarcane yield and some physical and chemical attributes of soil.

\section{Materials and Methods}

The research was performed in a 42 ha sugarcane field at the sugarcane mill Usina São João Açúcar e Álcool, in Araras, SP, Brazil. The area is located 166 $\mathrm{km}$ north of the city of São Paulo, in the Southeast

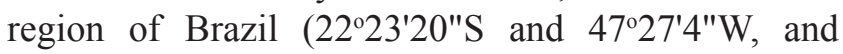
at $657 \mathrm{~m}$ altitude). One soil terrace divided the area along the northwest-south axis, and contour lines can be observed on Figure 1, which represents the experimental area. The rainfall pattern follows that of typical low-altitude tropical zones with rainy summers and dry winters. The average rainfall was $1,690 \mathrm{~mm}$ in the 2003/2004 season, and the climate is Aw, according to Köppen's classification. Based on a survey carried out on a 1:20.000 scale, the soils are predominantly Oxisols, specifically Typic Haplustox (Soil Survey Staff, 2003).

The sugarcane variety SP80-1816 was planted in 2001. Liming and fertilization were performed according to usual recommendations for sugarcane crop (Raij et al., 1997), at fixed rate. For the subsequent ratoon crops, a filter cake (source of $\mathrm{N}$ and $\mathrm{P}$ ) dose was applied at $16.8 \mathrm{Mg} \mathrm{ha}^{-1}$ and vinasse ( $\mathrm{K}$ source)

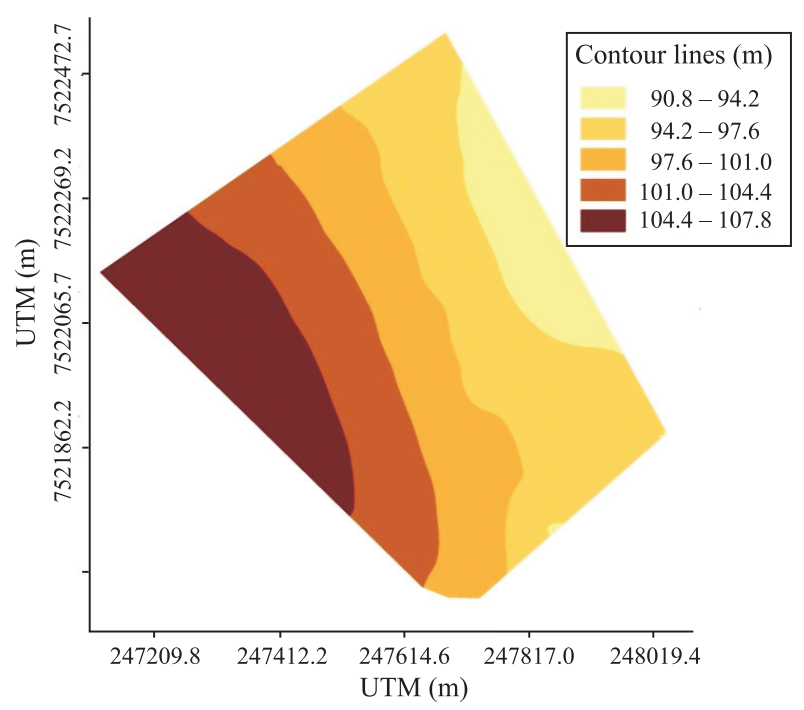

Figure 1. Area topography representation. 
at $59.7 \mathrm{~m}^{3} \mathrm{ha}^{-1}$, in December 2002. In December 2003, 20-00-30 ( $\left.-\mathrm{P}_{2} \mathrm{O}_{5}-\mathrm{K}_{2} \mathrm{O}\right)$ fertilizer was applied at $450 \mathrm{~kg} \mathrm{ha}^{-1}$. The area, presenting green sugarcane in its second ratoon, was mechanically harvested in November 2004. The area has a historical of more than 30 years with sugarcane.

Soil samples were collected with a regular square $100 \times 100 \mathrm{~m}$ grid, in the fall of 2003, from $0.0-0.2 \mathrm{~m}$ soil depth, using a Ford tractor adapted with a mechanical soil probe, a laptop computer, and a GPS unit (GEOExplorer III, Trimble Navigation Limited, Sunnyvale, CA, USA) to locate the selected sampling locations. The samples were corrected with a post-process differential signal, using correction files obtained from the Escola de Agricultura Luiz de Queiroz reference base station, located $20 \mathrm{~km}$ southwest of the area. A total of 46 samples with $69 \mathrm{~mm}$ diameter were taken, and each one was made from three core samples collected within a $5 \mathrm{~m}$ radius.

Prior to chemical analysis, the samples were air-dried and ground to pass through a $2 \mathrm{~mm}$ sieve. The laboratory analysis of soil properties included soil $\mathrm{pH}$, soil buffer $\mathrm{pH}$, available phosphorus $(\mathrm{P})$, exchangeable potassium $(\mathrm{K})$, calcium $(\mathrm{Ca})$, and magnesium $(\mathrm{Mg})$, which were extracted using the ion exchange resin method proposed by Raij et al. (1987). The determination of total carbon (C) and nitrogen (N) was performed by dry combustion, using a Leco CN-2000 analyzer (Leco Corporation, Saint Joseph, Michigan, USA). Based on the chemical analysis, the cation exchange capacity (CEC) and the base saturation percentage (BS) were calculated. Soil resistance to penetration tests was determined in accordance with standard Asae S313.3 (Asabe Standards, 2004) using an electronic penetrograph PNT 2000, (DLG Automação, Sertãozinho, SP, Brazil).

To map sugarcane yield, a sugarcane harvester Case A7700, (Case IH Agriculture, Piracicaba, SP, Brazil), equipped with yield monitor was used (Magalhães \& Cerri, 2007). The system uses load cells as a billet weighing instrument set up in the harvester side conveyor, before sugarcane billets are dropped in an infield wagon. These data, together with the information obtained by a GPS installed on the harvester, allowed generating a digital map using a geographical information system (GIS) that represented local production. Data acquisition accuracy was checked by comparing the weight spent to fill an infield wagon, measured by the yield monitor and the actual weight in the wagon.

Raw yield data normally show errors, thus a filtering process was performed in order to eliminate them. Collected data were processed to remove outliers and artefacts, and to better align the yield spatially. Null and negative yield values were removed. Yield values in the top 0.5 and bottom 2.5 percentiles were disregarded (Tukey, 1977). A three-second delay was added to the yield data to account for the time lag which occurs between the time sugarcane is harvested and the time it reaches the yield sensor.

Han et al. (1994) suggested that the area to be mapped should be divided into cells, and the dimensions of those cells should follow certain standards: for instance, speed and harvesting width of the combine, data-reading capacity and acquisition rate of the measurement, and positioning system. Considering the harvesting speed of $1.38 \mathrm{~m} \mathrm{~s}^{-1}$, sugarcane row separation of $1.5 \mathrm{~m}$, the fact that the combine only harvests one row at a time, and a period of $10 \mathrm{~s}$ for data acquisition, the average size of the adopted cells were approximately $20 \mathrm{~m}^{2}$.

The data were submitted to an exploratory and descriptive statistical analysis with the software ArcGis 8.3 (Environmental Systems Research Institute, Inc. (Esri), Redlands, CA, USA), calculating the mean, standard deviation, median, coefficient of variation (CV), asymmetry and kurtosis coefficient, and the maximum and minimum values. ArcGis was also used for the spatial dependence determination by ordinary kriging method, using the regionalized variable theory, which assumes the stationary and the intrinsic hypothesis. The cross validation method was used to test the adequacy of the model, which was adjusted for the data set of the semivariogram.

Finally, sugarcane yield map and the maps of physical and chemical soil attributes were constructed by block kriging as interpolation method. Block kriging has been used in the present work as it is often more useful to know the average value for an area than the value for a point (Mcbratney \& Pringle, 1999).

To correlate the sugarcane yield with physical and chemical soil attributes, linear correlation coefficient was used (5\% probability). The first step was to assign a value of yield for each grid point of soil sampling. To do this using the program ArcGis, a map with the spatial distribution of soil sampling points was overlaid on the non-interpolated yield map. For each soil 
sampling point, a circle of $50 \mathrm{~m}$ radius was created. The average yield contained inside the delimited circle was calculated and assigned to each soil sampling point, forming a single sheet with all the information. For statistical correlation analyses, it was used the average for each of the 12 physical and chemical properties, analysed over the root zone layer $(0-0.2 \mathrm{~m})$ at each collection point (46). Yield responses to individual soil properties were modelled with correlation index at 5\% probability, using Statgraph Plus 4.1 for Windows (Statistical Graphics Corporation, Warrenton, VA, USA).

\section{Results and Discussion}

Measured values varied considerably. Phosphorus and $\mathrm{K}$ showed a strong asymmetry (kurtosis and skewness), which indicates a non-normal distribution (Table 1). According to Cressie (1993), the normality of the data is not mandatory in geostatistics. The CV allows the comparison between different soil attributes. A high $\mathrm{CV}$ can be considered to be the first indicator of data heterogeneity. In the present work, the $\mathrm{CV}$ for $\mathrm{pH}$, $\mathrm{N}, \mathrm{C}, \mathrm{H}+\mathrm{Al}, \mathrm{CEC}$, BS showed low values $(<30 \%)$, but for $\mathrm{P}, \mathrm{K}^{+}, \mathrm{Ca}^{2+}, \mathrm{Mg}^{2+}$ and $\mathrm{CI}$ it had high values $(>30 \%)$, which could be indicative of which soil attributes directly contributed to the yield.

The semivariance analyses for those attributes showed that soil properties have different spatial dependences with low structure and a high-nugget effect (Table 2). Spherical models were defined for all the measured soil atributes. From these, carbon was the only one which showed a strong spatial dependence (DSD), i.e., a degree of spatial dependence

Table 1. Soil attribute values at $0-0.2-\mathrm{m}$ soil depth.

\begin{tabular}{|c|c|c|c|c|c|c|c|c|}
\hline Atribute & Mean & Median & SD & CV (\%) & Min & Max & Kurtosis & Skewness \\
\hline Clay $\left(\mathrm{g} \mathrm{kg}^{-1}\right)$ & 302.4 & 298.3 & 77.5 & 25.62 & 120.2 & 59.47 & 1.62 & 0.86 \\
\hline $\mathrm{pH} \mathrm{H} \mathrm{H}_{2} \mathrm{O}$ & 6.10 & 6.12 & 0.25 & 4.17 & 5.30 & 6.57 & 1.24 & -0.47 \\
\hline $\mathrm{pH} \mathrm{CaCl} 2$ & 5.58 & 5.64 & 0.43 & 7.80 & 4.68 & 6.30 & -0.99 & -0.10 \\
\hline $\mathrm{N}\left(\mathrm{g} \mathrm{kg}^{-1}\right)$ & 0.9 & 0.9 & 0.2 & 19.93 & 0.5 & 1.3 & -0.19 & 0.40 \\
\hline $\mathrm{C}\left(\mathrm{g} \mathrm{kg}^{-1}\right)$ & 13.3 & 12.8 & 2.5 & 18.86 & 7.5 & 18.9 & -0.02 & 0.19 \\
\hline Cone index $(\mathrm{MPa})$ & 0.73 & 0.67 & 0.41 & 56.09 & 0.14 & 1.83 & 0.08 & 0.81 \\
\hline $\mathrm{P}\left(\mathrm{mg} \mathrm{dm} \mathrm{m}^{-3}\right)$ & 28.70 & 20.00 & 26.20 & 91.31 & 4.00 & 115.00 & 5.00 & 2.37 \\
\hline $\mathrm{K}^{+}\left(\mathrm{mmol}_{\mathrm{c}} \mathrm{dm}^{-3}\right)$ & 1.33 & 1.05 & 0.71 & 53.00 & 0.40 & 3.30 & 1.53 & 1.36 \\
\hline $\mathrm{Ca}^{2+}\left(\mathrm{mmol}_{\mathrm{c}} \mathrm{dm}^{-3}\right)$ & 27.89 & 27.50 & 10.51 & 37.69 & 7.00 & 55.00 & -0.02 & 0.28 \\
\hline $\mathrm{Mg}^{2+}\left(\mathrm{mmol}_{\mathrm{c}} \mathrm{dm}^{-3}\right)$ & 11.41 & 11.00 & 4.19 & 36.69 & 4.00 & 21.00 & -0.56 & 0.21 \\
\hline $\mathrm{H}+\mathrm{AL}\left(\mathrm{mmol}_{\mathrm{c}} \mathrm{dm}^{-3}\right)$ & 27.48 & 26.50 & 6.77 & 24.66 & 18.00 & 52.00 & 2.62 & 1.19 \\
\hline $\mathrm{CEC}\left(\mathrm{mmol}_{\mathrm{c}} \mathrm{dm}^{-3}\right)$ & 68.11 & 66.95 & 11.44 & 16.79 & 45.50 & 94.00 & -0.34 & 0.03 \\
\hline BS (\%) & 58.28 & 60.50 & 13.34 & 22.86 & 20.00 & 79.00 & 0.64 & -0.87 \\
\hline
\end{tabular}

$\mathrm{SD}$, standard deviation; $\mathrm{CV}$, coefficient of variation $(\mathrm{n}=46)$

Table 2. Parameters for a semivariogram model fit.

\begin{tabular}{|c|c|c|c|c|c|c|}
\hline \multirow[t]{2}{*}{ Atribute } & \multirow[t]{2}{*}{ Model } & Nugget effect & Sill & \multirow{2}{*}{$\begin{array}{l}\text { Range } \\
(\mathrm{m})\end{array}$} & \multirow{2}{*}{$\begin{array}{c}\text { Spatial dependence }{ }^{(1)} \\
(\%)\end{array}$} & \multirow[t]{2}{*}{ Class $^{12}$} \\
\hline & & \multicolumn{2}{|c|}{----------------(Units)---------------- } & & & \\
\hline$\overline{\mathrm{pH} \mathrm{H}} \mathrm{H}_{2} \mathrm{O}$ & Spherical & 0.060 & 0.066 & 503 & 91 & $\mathrm{R}$ \\
\hline $\mathrm{pH} \mathrm{CaCl}{ }_{2}$ & Spherical & 0.174 & 0.204 & 1045 & 86 & $\mathrm{R}$ \\
\hline $\mathrm{N}$ & Spherical & 0.00011 & 0.00035 & 476 & 33 & M \\
\hline $\mathrm{C}$ & Spherical & 0.0168 & 0.0706 & 419 & 24 & $\mathrm{~S}$ \\
\hline Cone index & Spherical & 0.0963 & 0.1728 & 298 & 56 & M \\
\hline $\mathrm{P}$ & Spherical & 82.48 & 118.03 & 550 & 70 & M \\
\hline $\mathrm{K}^{+}$ & Spherical & 0.49746 & 0.49746 & 500 & 100 & $\mathrm{R}$ \\
\hline $\mathrm{Ca}^{2+}$ & Spherical & 98.55 & 121.10 & 987 & 81 & $\mathrm{R}$ \\
\hline $\mathrm{Mg}^{2+}$ & Spherical & 16.85 & 17.61 & 338 & 96 & $\mathrm{R}$ \\
\hline $\mathrm{H}+\mathrm{Al}$ & Spherical & 37.81 & 47.752 & 481 & 79 & $\mathrm{R}$ \\
\hline CEC & Spherical & 98.916 & 134.275 & 378 & 74 & M \\
\hline $\mathrm{BS}$ & Spherical & 166.59 & 180.803 & 500 & 92 & $\mathrm{R}$ \\
\hline
\end{tabular}

${ }^{(1)}$ Degree of spatial dependence: $[\mathrm{C} 0 /(\mathrm{C} 0+\mathrm{C})] 100 .{ }^{(2)}$ Classes: S, strong; M, moderate; R, random. 
$[\mathrm{C} 0 /(\mathrm{C} 0+\mathrm{C} 1)] 100$ lower than $25 \%$, according to Cambardella \& Karlen (1999).

Amado et al. (2009) investigated the relationship of physical and chemical soil attributes with corn and common bean yields, and also reported that chemical properties showed a strong spatial dependence, whereas $\mathrm{P}$ showed the highest spatial variability and $\mathrm{pH}$ the lowest one.

Figure 2 shows the maps for $\mathrm{P}, \mathrm{K}, \mathrm{BS}$, and clay contents at $0-0.2 \mathrm{~m}$. Those attributes are the most commonly ones used in the diagnosis of sugarcane nutrition.

Sugarcane yield map showed that, in $48 \%$ of the area, yield was between 64 and $94 \mathrm{Mg} \mathrm{ha}^{-1}$, and that the values between 6 and $64 \mathrm{Mg} \mathrm{ha}^{-1}$ appear at isolated locations of low productivity Figure 3. The average yield during the season was $89.9 \mathrm{Mg} \mathrm{ha}^{-1}$ for the whole area, which is a good productive performance, if compared with the historical values of previous yields, by which planted cane yielded $89.3 \mathrm{Mg} \mathrm{ha}^{-1}$, and first ratoon cane $79.3 \mathrm{Mg} \mathrm{ha}^{-1}$.
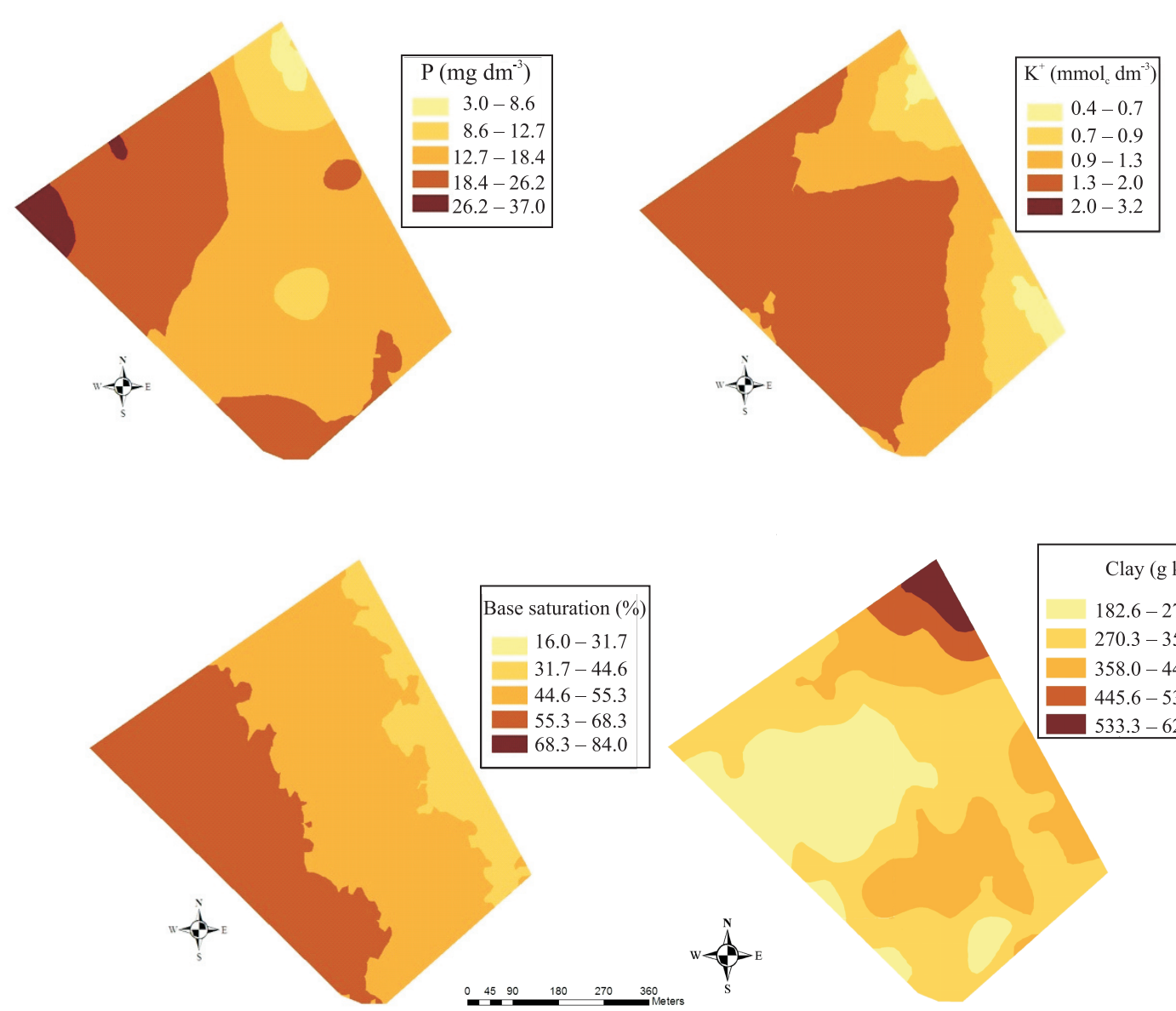
a similar pattern following the area relief. Siqueira et al. (2010) reported that the division of the area in landforms helped the understanding of the interrelations of physical and hydrological soil attributes with crop yield.

Correlation values between soil attributes and sugarcane yield were lower than $0.5(\mathrm{p}<0.05)$ for most soil attributes (Table 3 ). These low correlations confirm the tendency observed by other researchers (Yanai et al., 2001; Frogbrook et al.; 2002; Pontelli, 2006) that physical and chemical soil attributes alone are insufficient to explain spatial yield variability of a crop. To overcome this difficulty, Santi (2007) proposed the use of the principal component analysis to define which attributes are decisive in the variability of the production areas. The author investigated which soil chemical and physical attributes could explain most of the total variability in the area, and their relationship with the relative yield of crops.

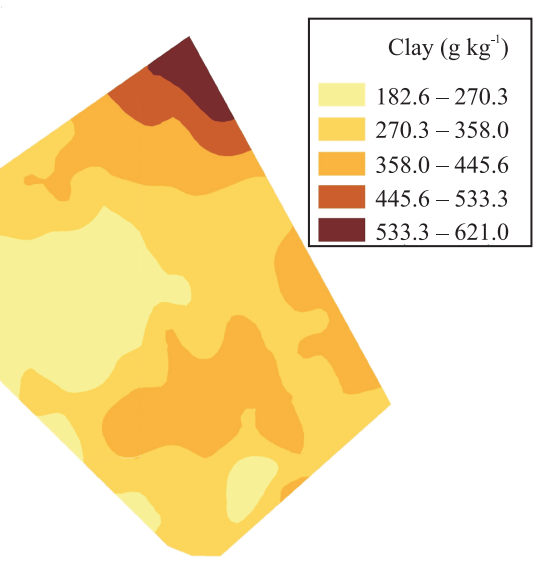

Figure 2. Maps of soil attributes for $\mathrm{P}, \mathrm{K}$, base saturation, and clay content at $0-0.2-\mathrm{m}$ soil depths. 
Yield was positively correlated with C (0.41), N (0.33), SOM (0.44), and $\mathrm{H}+\mathrm{Al}(0.32)$, and negatively correlated with $\mathrm{P}(-0.24)$. These results confirm the benefits of the SOM for yield reported by Rossetto et al. (2008). Nevertheless, the negative correlation between yield and $\mathrm{P}$ contents in soil was not expected. Beauclair (1991) reported the influence of phosphorus on the yield of the first two harvests, and stressed the importance of this nutrient for sugarcane, especially on the yield of the $1^{\text {st }}$ harvest.

Clay contents explained $22 \%$ of the yield variance. Timm et al. (2003) found that no more than $34 \%$ of the

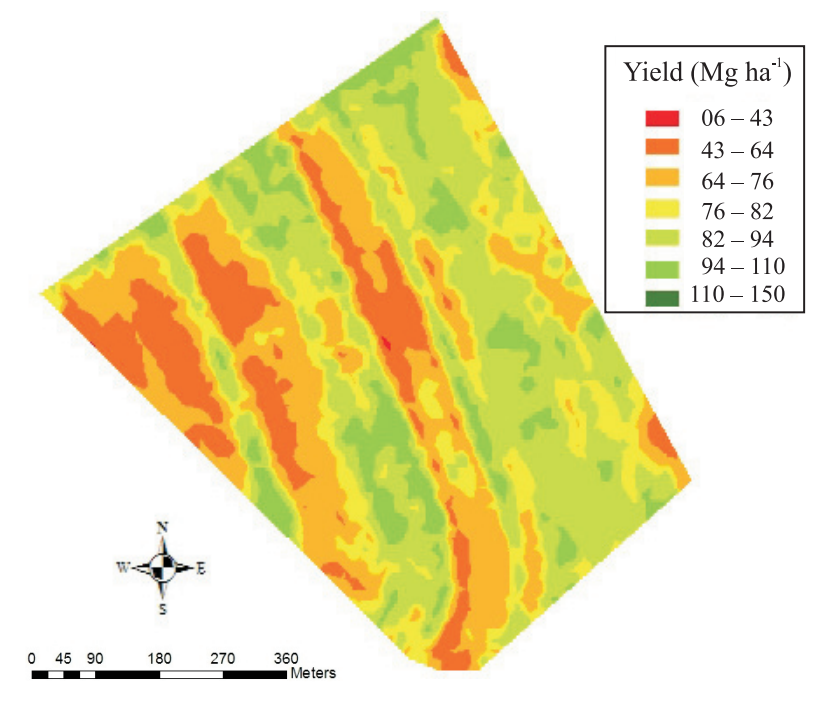

Figure 3. Sugarcane yield map after kriging. variance in number of canes could be explained with linear regression using clay contents.

Soil resistance to penetration $(\mathrm{CI})$ showed a moderate negative correlation with yield $(-0.27)$, which may explain the yield pattern following the area contour lines and relief.

Similarly to $\mathrm{P}, \mathrm{pH}$ in $\mathrm{CaCl}_{2}$ showed a negative correlation with productivity (-0.29), but a high positive correlation with CEC (0.58). Although the range of $\mathrm{pH}$ variation in the area $(\mathrm{CV} \sim 8 \%)$ was small, it showed a relative high correlation with crop productivity. These results are in accordance with those of Beauclair (1991) and Landell et al. (2003), who showed that $\mathrm{pH}$ at depths between 0 and $0.25 \mathrm{~m}$ had good correlation with crop yield, until the $3^{\text {rd }}$ harvest.

Also unexpectedly, base saturation did not show positive correlation with yield (-0.154). Eutrophic soils with high values of BS are expected to have a superior yield because macronutrient availability progressively decreases as BS decreases.

To explain the variability of sugarcane yield, other information, such as drainage and moisture status of the soil, and weeds, pests and diseases infestations, among others, should be obtained and incorporated into the evaluation. Soil density values - not determined in the present study - were most likely negatively correlated with yield. Observing the map of soil density distribution in the area, obtained in the previous year (Figure 4), it is possible to observe that locations with high soil density was coincident with the region low yield ones.

Table 3. Linear correlation matrix between yield and soil attributes at $0-0.20-\mathrm{m}$ soil depth.

\begin{tabular}{|c|c|c|c|c|c|c|c|c|c|c|c|c|c|c|}
\hline & Clay & $\mathrm{pH} \mathrm{H} \mathrm{H}_{2} \mathrm{O}$ & $\mathrm{pH} \mathrm{CaCl}{ }_{2}$ & $\mathrm{~N}$ & $\mathrm{C}$ & C.I. & SOM & $\mathrm{P}$ & $\mathrm{K}^{+}$ & $\mathrm{Ca}^{2+}$ & $\mathrm{Mg}^{2+}$ & $\mathrm{H}+\mathrm{Al}$ & CEC & BS \\
\hline $\mathrm{pH} \mathrm{H} \mathrm{H}_{2} \mathrm{O}$ & 0.187 & & & & & & & & & & & & & \\
\hline $\mathrm{pH} \mathrm{CaCl}{ }_{2}$ & -0.061 & 0.680 & & & & & & & & & & & & \\
\hline $\mathrm{N}$ & 0.506 & 0.239 & 0.253 & & & & & & & & & & & \\
\hline $\mathrm{C}$ & 0.533 & 0.205 & 0.143 & 0.935 & & & & & & & & & & \\
\hline C.I. & -0.245 & -0.122 & -0.099 & -0.343 & -0.328 & & & & & & & & & \\
\hline SOM & 0.504 & 0.162 & 0.106 & 0.825 & 0.900 & -0.263 & & & & & & & & \\
\hline $\mathrm{P}$ & -0.210 & 0.219 & 0.407 & 0.225 & 0.128 & 0.065 & 0.103 & & & & & & & \\
\hline $\mathrm{K}^{+}$ & -0.007 & 0.144 & 0.160 & 0.259 & 0.194 & -0.197 & 0.117 & 0.166 & & & & & & \\
\hline $\mathrm{Ca}^{2+}$ & 0.102 & 0.708 & 0.819 & 0.517 & 0.439 & -0.186 & 0.422 & 0.552 & 0.145 & & & & & \\
\hline $\mathrm{Mg}^{2+}$ & 0.369 & 0.775 & 0.739 & 0.470 & 0.441 & -0.281 & 0.411 & 0.184 & 0.011 & 0.829 & & & & \\
\hline $\mathrm{H}+\mathrm{Al}$ & 0.221 & -0.699 & -0.764 & 0.054 & 0.150 & -0.028 & 0.199 & -0.293 & -0.194 & -0.607 & -0.536 & & & \\
\hline CEC & 0.183 & 0.530 & 0.581 & 0.695 & 0.665 & -0.302 & 0.663 & 0.411 & 0.084 & 0.872 & 0.811 & -0.174 & & \\
\hline BS & 0.360 & 0.789 & 0.893 & 0.293 & 0.198 & -0.134 & 0.169 & 0.386 & 0.197 & 0.899 & 0.829 & -0.851 & 0.637 & \\
\hline Yield & 0.270 & -0.053 & -0.290 & 0.333 & 0.407 & -0.267 & 0.440 & -0.242 & -0.004 & -0.059 & 0.011 & 0.317 & 0.138 & -0.154 \\
\hline
\end{tabular}

C.I., cone index; SOM, soil organic matter. 


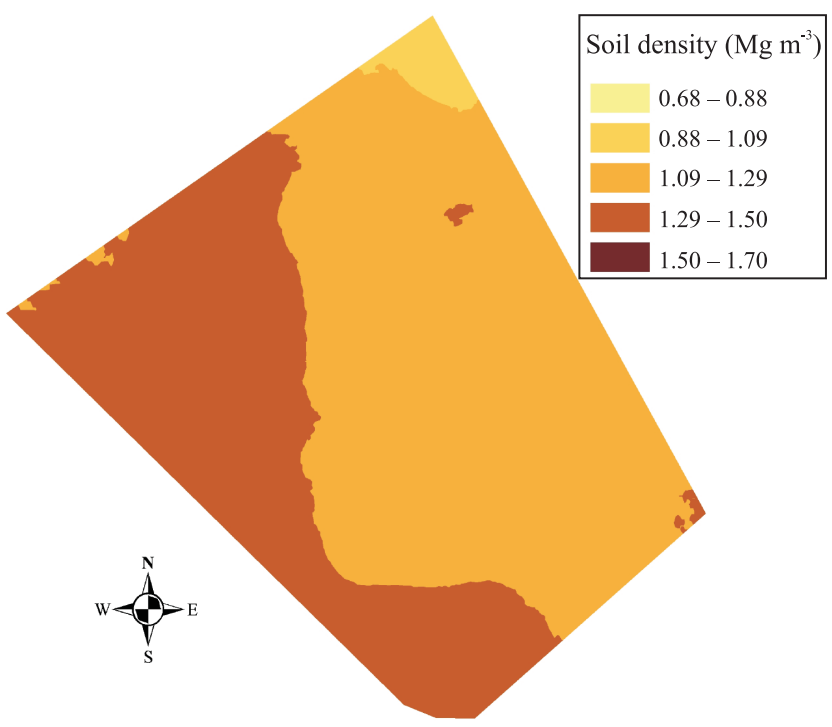

Figure 4. Soil density in the area previously from the analysed cropping season.

Other variables besides soil properties should be addressed when determining sugarcane yield; besides that, statistical procedures, such as factor analysis, principal component analysis, Kapa index, neural networks, among others, should have its application tested in order to better understand the factors controlling sugarcane yield.

\section{Conclusions}

1. Correlations of chemical and physical soil attributes with sugarcane yield are weak, which indicates that they are not able to properly explain variation in it.

2. The most important attributes which positively influence sugarcane yield are $\mathrm{C}, \mathrm{N}$, and $\mathrm{H}+\mathrm{Al}$; and the ones that negatively influence are $\mathrm{pH} \mathrm{CaCl}, \mathrm{P}$ and cone index.

\section{Acknowledgements}

To Fundação de Amparo à Pesquisa do Estado de São Paulo, to Financiadora de Estudos e Projetos, and to Conselho Nacional de Desenvolvimento Científico e Tecnológico, for funding; to Usina São João, for allowing of the experimental area, and for providing the necessary support and cooperation during the initial field tests.

\section{References}

AMADO, T.J.C.; PES, L.Z.; LEMAINSKI, C.L.; SCHENATO, R.B. Atributos químicos e físicos de latossolos e sua relação com os rendimentos de milho e feijão irrigados. Revista Brasileira de Ciência do Solo, v.33, p.831-843, 2009.

ASABE STANDARDS. ASAE S313.3: soil cone penetrometer. St. Joseph: American Society of Agricultural and Biological Engineers, 2004.

BEAUCLAIR, E.G.F. Relações entre algumas propriedades químicas do solo e a produtividade da cana-de-açúcar (Saccharum spp.), através de regressão linear múltipla. 1991. 90p. Dissertação (Mestrado) - Universidade de São Paulo, Piracicaba.

BORGELT, S.C.; SEARCY, S.W.; STOUT, B.A.A.; MULLA, D.J. Spatially variable liming rates: a method for determination. Transactions of the ASAE, v.37, p.1499-1507, 1994.

CAMBARDELLA, C.A.; KARLEN, D.L. Spatial analysis of soil fertility parameters. Precision Agriculture, v.1, p.5-14, 1999.

CANTARELLA, H.; ROSSETTO, R. Fertilizers for sugar cane. In: CORTEZ, L.A.B. (Ed.). Sugarcane bioethanol. São Paulo: Blucher, 2010. p.405-422.

CORÁ, J.E.; ARAUJO, A.V.; PEREIRA, G.T.; BERALDO, J.M.G. Assessment of spatial variability of soil attributes as a basis for the adoption of precision agriculture in sugarcane plantations. Revista Brasileira de Ciência do Solo, v.28, p.1013-1021, 2004.

CORÁ, J.E.; BERALDO, J.M.G. Variabilidade espacial de atributos do solo antes e após calagem e fosfatagem em doses variadas na cultura de cana-de-açúcar. Engenharia Agrícola, v.26, p.374-387, 2006.

CRESSIE, N.A.C. Statistics for spatial data. New York: John Wiley, 1993. 900p.

FROGBROOK, Z.L.; OLIVER, M.A.; SALAHI, M.; ELLIS, R.H. Exploring the spatial relations between cereal yield and soil chemical properties and the implications for sampling. Soil Use and Management, v.18, p.1-9, 2002.

GODWIN, R.J.; RICHARDS, T.E.; WOOD, G.A.; WELSH, J.P.; KNIGHT, S.M. An economic analysis of the potential for precision farming in UK cereal production. Biosystems Engineering, v.84, p.533-545, 2003

GOERING, C.E. Recycling a concept. Agricultural Engineering, v.74, p.25, 1993.

HAN, S.; HUMMEL, J.W.; GOERING, C.E.; CAHN, M.D. Cell size selection for site specific crop management. Transaction of the ASAE, v.37, p.19-26, 1994.

HURTADO, S.M.C.; RESENDE, A.V. de; SILVA, C.A.; CORAZZA, E.J.; SHIRATSUCHI, L.S. Variação espacial da resposta do milho à adubação nitrogenada de cobertura em lavoura no Cerrado. Pesquisa Agropecuária Brasileira, v.44, p.300-309, 2009.

JOHNSON, R.M.; RICHARD, E.P. Sugarcane yield, sugarcane quality, and soil variability in Louisiana. Agronomy Journal, v.97, p.760-771, 2005. 
JOHNSON, R.M.; RICHARD, E.P. Variable-rate lime application in Louisiana sugarcane production systems. Precision Agriculture, v.11, p.464-474, 2010.

KRAVCHENKO, A.N.; BULLOCK, D.G. Correlation of corn and soybean grain yield with topography and soil properties. Agronomy Journal, v.92, p.75-83, 2000.

LANDELL, M.G. de A.; PRADO, H. do; VASCONCELOS, A.C.M. de; PERECIN, D.; ROSSETTO, R.; BIDOIA, M.A.P.; SILVA, M. de A.; XAVIER, M.A. Oxisol subsurface chemical attributes related to sugarcane productivity. Scientia Agricola, v.60, p.741-745, 2003.

MCBRATNEY, A.B.; PRINGLE, M.J. Estimating average and proportional variograms of soil properties and their potential use in precision agriculture. Precision Agriculture, v.1, p.125-152, 1999.

MAGALHÃES, P.S.G.; CERRI, D.G.P. Yield monitoring of sugar cane. Biosystems Engineering, v.96, p.1-6, 2007.

MALLARINO, A.P.; WITTRY, D.J. Efficacy of grid and zone soil sampling approaches for site-specific assessment of phosphorus, potassium, $\mathrm{pH}$, and organic matter. Precision Agriculture, v.5, p.131-14, 2004.

PONTELLI, C.B. Caracterização da variabilidade espacial das características químicas do solo e da produtividade das culturas utilizando as ferramentas da agricultura de precisão. 2006. 111p. Dissertação (Mestrado) - Universidade Federal de Santa Maria, Santa Maria.

RAIJ, B. van; CANTARELLA, H.; QUAGGIO, J.A.; FURLANI, A.M.C. (Ed.). Recomendação e calagem para o Estado de São Paulo. 2.ed. Campinas: IAC, 1997. 285p. (IAC. Boletim técnico, 100).

RAIJ, B. van; QUAGGIO, J.A.; CANTARELLA H.; FERREIRA, M.E.; LOPES, A.S.; BATAGLIA, O.C. Análise química do solo para fins de fertilidade. Campinas: Fundação Cargill, 1987. 170p.
ROSSETTO, R.; CANTARELLA, H.; DIAS, F.L.F.; LANDELL, M.G.A.; VITTI, G.C. Manejo conservacionista e reciclagem de nutrientes em cana-de-açúcar tendo em vista a colheita mecânica. Informações Agronômicas, v.124, p.8-13, 2008.

SANTI, A.L. Relações entre indicadores de qualidade do solo e a produtividade das culturas em áreas com agricultura de precisão. 2007. 175p. Tese (Doutorado) - Universidade Federal de Santa Maria, Santa Maria.

SIQUEIRA, D.S.; MARQUES JÚNIOR, J.; PEREIRA, G.T. The use of landforms to predict the variability of soil and orange attributes. Geoderma, v.155, p.55-66, 2010.

SOIL SURVEY STAFF. Keys to soil taxonomy. $9^{\text {th }}$ ed. Washington: Department of Agriculture: National Resources Conservation Service, 2003. 332p

SOUZA Z.M.; MARQUES JÚNIOR, J.; PEREIRA, G.T.; BENTO, M.J.C. Variabilidade espacial de atributos físicos de um Latossolo Vermelho sob cultivo de cana-de-açúcar. Revista Brasileira de Engenharia Agrícola Ambiental, v.8, p.51-58, 2004.

TIMM, L.C.; REICHARDT, K.; OLIVEIRA, J.C.M.; CASSARO, F.AM.; TOMINAGA, T.T.; BACCHI, O.O.S.; DOURADO-NETO, D. Sugarcane production evaluated by the state-space approach. Journal of Hydrology, v.272, p.226-237, 2003.

TUKEY, J.W. Exploratory data analysis. Reading: Addison-Wesley, 1977. 506p.

WELSH, J.P.; WOOD, G.A.; GODWIN, R.J.; TAYLOR, J.C.; EARL, R.; BLACKMORE, S.; KNIGHT, S. Developing strategies for spatially variable nitrogen application in cereals, part I: winter barley. Biosystems Engineering, v.84, p.481-494, 2003.

YANAI, J.; LEE, C.K.; KAHO, T.; IIDA, M.; MATSUI, T.; UMEDA, M.; KOSAKI, T. Geostatistical analysis of soil chemical properties and rice yield in a paddy field and application to the analysis of yield-determining factors. Soil Science and Plant Nutrition, v.47, p.291-301, 2001.

Received on November 20, 2010 and accepted on February 29, 2012

Pesq. agropec. bras., Brasília, v.47, n.4, p.613-620, abr. 2012 